\title{
Women's Participation in Kitchen Gardening in Hilly Areas of Nepal
}

\section{Sujan Ghimire* \\ Department of Agricultural Economics and Agribusiness Management, AFU, Nepal}

*Corresponding Author: Sujan Ghimire, Department of Agricultural Economics and Agribusiness Management, AFU, Nepal.

Received: June 05, 2019; Published: July 25, 2019

DOI: 10.31080/ASAG.2019.03.0585

\begin{abstract}
The research study was conducted in the heterogeneous communities of the Palungtar Municipality (Gorkha), Rainas Municipality (Lamjung), Bhanu Municipality (Tanahun), Sundarbazar Municipality (Lamjung) and Kathmandu Metropolitan city (Kathmandu) during Oct-Nov, 2018. The objectives of this research were to explore the existing situation, the extent of decision making, the labor and time contribution of women in kitchen gardening in hilly areas of Nepal. The data were collected through simple random sampling using pre-tested interview schedule on the existing situation of kitchen gardening and role of men and women. The literacy rates were almost similar in village but in Bhanu municipality (Tanahun) was higher than other sites. Educated mass was highest in Kathmandu and lowest in Sundarbazar (Lamjung). Kitchen gardening was found in underdeveloped stage. People were using local cultivars and traditional practices because they were devoid of technical knowledge and improved inputs. It was found that land allotted for kitchen gardening was very less in terms of total land holding. In most of the activities women had great role in decision making and some decisions were found to be made jointly. Women provided heavy contribution on kitchen gardening especially in nursery raising, sowing, transplanting, weeding, manuring, irrigation and harvesting. Men were more engaged for the preparation of land than women. Insect-pest, diseases and lack of irrigation, improved seeds, fertilizers, credit, extension and marketing facilities and climatic hazards were the major constraints faced by the farmers.
\end{abstract}

Keywords: Kitchen Gardening; Women's Participation; Decision Making

\section{Introduction}

Agriculture is predominantly women's activity in rural Nepal. About $86 \%$ of the population in Nepal lives in rural areas and make their livelihoods solely from agriculture [1]. Agricultural sector still shares a large portion of national economy. Women are contributing major portion (55-58\%) compared to men (40.80\%) to the National agriculture labor [2]. In Nepal, 72\% households have kitchen gardens of an area $2-11 \%$ of the total land holdings [3].

Women are as critical to agriculture production as their opposite sex counterparts. But their access to resources and effective technologies is often constrained by gender barriers. There has been also serious discrimination against women in their access to development resources and services resulting great illiteracy, poor health, social ill and inequality everywhere [4].
Kitchen gardening is an integral part of farming system from which fresh vegetables can be obtained. Vegetables are the source of carbohydrates, proteins, fats, vitamins and minerals, the lack of which in daily diets has been a primary cause of malnutrition and under nutrition. Home garden in Nepal have multiple uses: as a source of livelihood, firewood and timber, spices and medicinal plants, green manure and pesticides [5]. The promotion of vegetable cultivation among small farm-holders can be source of significant supplementary income and thus contributes to poverty alleviation. In our context people of hilly areas are suffering from malnutrition and under nutrition than the terai people thus kitchen gardening has greater scope in such regions [6].

Women are engaged in day to day cooking activities in the households. This makes them more important on kitchen gardening activities for the procurement of fresh vegetables in sufficient amount 
daily. Women's participation in agriculture development especially in kitchen gardening activities such as land preparation, seedling transplantation, irrigation, harvesting and in many instances they also make important farm decisions [7]. This research focuses on a comparison of women's role in kitchen gardening in 5 hilly areas of four districts of Nepal. They are Palungtar Municipality (Gorkha), Rainas Municipality (Lamjung), Bhanu Municipality (Tanahun) and Sundarbazar Municipality (Lamjung) and Kathmandu Metropolitancity (Kathmandu). The objectives of this research were to explore the existing situation, the extent of decision making, the labor and time contribution of women in kitchen gardening.

\section{Methodology}

This research was conducted in the heterogeneous communities of the Palungtar Municipality (Gorkha), Rainas Municipality (Lamjung), Bhanu Municipality (Tanahun) and Sundarbazar Municipality (Lamjung) and Kathmandu Metropolitan city (Kathmandu) during Oct-Nov (2018). Palungtar municipality is typical of the multiethnic communities in Gorkha district, mid hill of Nepal. It is populated by Brahmin, Chhetri, Newar, Gurung groups. Rainas municipality and Sundarbazar municipality (Lamjung) are located in mid hills of Nepal. Their geographical pattern is almost similar. Brahmin and Chhetri people are more in Rainas municipality where as population of Sundarbazar municipality is dominated by Gurung people. Bhanu municipality (Tanahun), mid hill of Nepal is composed of multiethnic groups and castes, whereas Kathmandu metropolitan city is a valley area characterized by multiethnic migrant city people in indigenous Newar groups.
The socio-economic and agro-climatic conditions of 4 locations except Kathmandu valley is almost similar where as relatively richer and more educated people live in Kathmandu. The data were collected through random sampling. The data were collected through an interview schedule on the existing situation of kitchen gardening and role of men and women farmers in terms of time and labor contribution and decision making. At each location households were selected through random sampling. After analysis of data existing situations were identified and comparative evaluation of women's role in kitchen gardening was done with recommendation.

In the survey there were two sections; one for interviewing men and another for interviewing women. Both men and women were interviewed and their response was recorded. The male section was answered by the household's heads in the most cases; while female section was represented by the most senior lady in the household.

\section{Results and Discussions}

The results of the survey are discussed in terms of gender differences in existing situation, extent of decision making, labor and time contribution of women in kitchen gardening.

\section{Existing situation}

The literacy rates were almost similar in village but in Bhanu municipality (Tanahun) was higher than other sites. Educated mass was highest in Kathmandu and lowest in Sundarbazar (Lamjung) (Table 1).

\begin{tabular}{|l|c|c|c|c|c|}
\hline $\begin{array}{l}\text { Education } \\
\text { Level }\end{array}$ & $\begin{array}{c}\text { Tanahun } \\
\text { (Bhanu } \\
\text { municipality) }\end{array}$ & $\begin{array}{c}\text { Lamjung } \\
\text { (Rainas } \\
\text { municipality) }\end{array}$ & $\begin{array}{c}\text { Kathmandu } \\
\text { (Kathmandu } \\
\text { Metro.) }\end{array}$ & $\begin{array}{c}\text { Gorkha } \\
\text { (Palungtar } \\
\text { municipality) }\end{array}$ & $\begin{array}{c}\text { Lamjung } \\
\text { (Sundarbazar } \\
\text { municipality) }\end{array}$ \\
\hline Illiterate & 30 & 35 & 20 & 40 & 50 \\
\hline Literate & 63 & 60 & 40 & 51 & 47 \\
\hline Educated & 7 & 5 & 40 & 9 & 3 \\
\hline
\end{tabular}

Table 1: Educational status (\%)

Kitchen gardening was found in underdeveloped stage. People were using local cultivars and traditional practices because they were devoid of technical knowledge and improved inputs. We found that land allotted for kitchen gardening was very less in terms of total land holding (Table 2). For example Palungatar (Gorkha) had highest total land holding but less land for kitchen gardening. However, there was highest land for kitchen gardening in Kathmandu in terms of total land. 


\begin{tabular}{|l|c|c|c|}
\hline Research sites & $\begin{array}{c}\text { Total land } \\
\text { (mean) }\end{array}$ & $\begin{array}{c}\text { Land occupied by kitchen } \\
\text { gardening (mean) }\end{array}$ & $\begin{array}{c}\text { \% land occupied by kitchen } \\
\text { gardening (mean) }\end{array}$ \\
\hline Tanahun (Bhanu municipality) & $29-0-0-0$ & $0-10-0-0$ & 2.16 \\
\hline Lamjung (Rainas municipality) & $15-0-0-0$ & $1-0-0-0$ & 6.67 \\
\hline Kathmandu (Kathmandu metro) & $0-12-0-0$ & $0-4-0-0$ & 33.33 \\
\hline Gorkha (Palungtar municipality) & $56-0-0-0$ & $0-10-0-0$ & 1.12 \\
\hline Lamjung (Sundarbazar municipality) & $15-5-0-0$ & $0-7-0-0$ & 2.86 \\
\hline
\end{tabular}

Table 2: Total land and land occupied by kitchen gardening (both in mean).

Note: Ropani-Ana-Paisa-Dam

\section{Decision making}

One of the objectives of this study was to access the extent that women make decisions concerning farm and household activities. The questions were asked about decisions related to the allocation of farm or household tasks and on the marketing, sales and purchase of needed items.
Table 3 illustrates that women in Rainas municipality had a slightly higher decision making role in most of the activities such as household work, kitchen gardening and input purchasing than in other areas. In most of the activities women had great role in decision making and some decisions were found to be made jointly.

\begin{tabular}{|c|c|c|c|c|c|c|c|c|c|c|c|c|c|c|c|c|c|c|c|c|c|c|c|c|c|}
\hline Activities & \multicolumn{5}{|c|}{$\begin{array}{l}\text { Tanahun (Bhanu } \\
\text { municipality) }\end{array}$} & \multicolumn{5}{|c|}{$\begin{array}{l}\text { Lamjung (Rainas } \\
\text { municipality) }\end{array}$} & \multicolumn{6}{|c|}{$\begin{array}{c}\text { Kathmandu } \\
\text { (Kathmandu metro) }\end{array}$} & \multicolumn{5}{|c|}{$\begin{array}{c}\text { Gorkha (Palungtar } \\
\text { municipality) }\end{array}$} & \multicolumn{4}{|c|}{$\begin{array}{c}\text { Lamjung } \\
\text { (Sundarbazar } \\
\text { municipality) }\end{array}$} \\
\hline $\begin{array}{l}\text { Household } \\
\text { work }\end{array}$ & 5 & 90 & - & 5 & - & 5 & 95 & - & - & - & - & 95 & - & 5 & - & - & 100 & - & - & - & 4 & 96 & - & - & - \\
\hline $\begin{array}{l}\text { Farm } \\
\text { activities }\end{array}$ & 30 & - & - & 70 & - & 95 & - & - & 5 & - & - & 50 & - & 20 & 50 & 50 & 33 & 17 & - & - & 90 & 10 & - & - & - \\
\hline $\begin{array}{l}\text { Kitchen } \\
\text { Gardening }\end{array}$ & - & 90 & - & 10 & - & - & 95 & - & 5 & - & - & 80 & - & 20 & 17 & 17 & 63 & - & - & - & 7 & 90 & - & - & - \\
\hline Marketing & 10 & 35 & - & 55 & - & 50 & 50 & - & - & - & - & 40 & - & 60 & 50 & 50 & 33 & 17 & - & - & 14 & 12 & - & 74 & - \\
\hline $\begin{array}{l}\text { Palnt protec- } \\
\text { tion meaures }\end{array}$ & - & 27 & - & 33 & 40 & 60 & 20 & - & 10 & 10 & 40 & 20 & - & - & 33 & 33 & - & - & 17 & 50 & 20 & 10 & - & - & 70 \\
\hline $\begin{array}{l}\text { Input } \\
\text { mobilization }\end{array}$ & 6 & 35 & - & 59 & - & 80 & 20 & - & - & - & 10 & 10 & - & 80 & 50 & 50 & 17 & - & 33 & - & 20 & 14 & - & 66 & - \\
\hline $\begin{array}{l}\text { Product } \\
\text { selling }\end{array}$ & 5 & - & - & 5 & 90 & - & 20 & - & 80 & - & - & 20 & - & - & 10 & 10 & 45 & - & - & 45 & 10 & 14 & - & - & 76 \\
\hline
\end{tabular}

Table 3: Gender involvement of decision making in household and farm activities (\%).

Note: $\mathrm{M}=\mathrm{Men}, \mathrm{W}=$ Women, $\mathrm{C}=$ Children, J=Joint, NA= Not Applicable 
Labor and time contribution

The results of the labor participation in kitchen gardening (Table 4) demonstrates that women provided heavy contribution on kitchen gardening especially in nursery raising, sowing, transplanting, weeding, manuring, irrigation and harvesting. Men were more engaged for the preparation of land than women.

\begin{tabular}{|c|c|c|c|c|c|c|c|c|c|c|c|c|c|c|c|}
\hline \multirow[t]{2}{*}{ Activities } & \multicolumn{3}{|c|}{$\begin{array}{c}\text { Tanahun (Bhanu } \\
\text { municipality) }\end{array}$} & \multicolumn{3}{|c|}{$\begin{array}{c}\text { Lamjung } \\
\text { (Rainas } \\
\text { municipality) }\end{array}$} & \multicolumn{3}{|c|}{$\begin{array}{c}\text { Kathmandu } \\
\text { (Kathmandu } \\
\text { metro) }\end{array}$} & \multicolumn{3}{|c|}{$\begin{array}{c}\text { Gorkha (Palungtar } \\
\text { municipality) }\end{array}$} & \multicolumn{3}{|c|}{$\begin{array}{l}\text { Lamjung (Sundar- } \\
\text { bazar municipality }\end{array}$} \\
\hline & $\mathbf{M}$ & W & C & $\mathbf{M}$ & $\mathbf{W}$ & C & $\mathbf{M}$ & $\mathbf{W}$ & C & $\mathbf{M}$ & $\mathbf{W}$ & C & $\mathbf{M}$ & $\mathbf{W}$ & C \\
\hline $\begin{array}{l}\text { Ploughing/land } \\
\text { preparation }\end{array}$ & 3 & 1 & - & 6 & 6 & - & 2 & 2 & - & 2 & 4 & - & 4 & - & - \\
\hline Nursery raising & 1 & 2 & - & - & 6 & - & 1 & - & - & 1 & 2 & - & 2 & 2 & - \\
\hline $\begin{array}{l}\text { Sowing transplant- } \\
\text { ing }\end{array}$ & 1 & 3 & - & - & 8 & - & 1 & 3 & - & 4 & 4 & - & - & - & 2 \\
\hline Weeding & - & 3 & - & - & 6 & - & - & 2 & - & 2 & 3 & - & - & 3 & - \\
\hline Manuring & - & 2 & - & - & 8 & - & - & 1 & - & - & 2 & - & - & 3 & - \\
\hline Irrigation & 2 & 13 & 1 & 1 & 15 & 2 & 2 & 6 & - & - & 18 & - & 1 & 4 & 2 \\
\hline Harvesting & - & 4 & - & - & 10 & 2 & - & 4 & - & - & 8 & - & 1 & 4 & 2 \\
\hline
\end{tabular}

Table 4: Labor participation (average hours/season) in kitchen gardening.

\section{Note: $\mathrm{M}=\mathrm{Men}, \mathrm{W}=$ Women, $\mathrm{C}=$ Children}

Table illustrates that in most of the study area the labor used for kitchen gardening was only family labor but in Rainas Municipality (Lamjung) also used exchange labor specially women. Hired labor used in Kathmandu and Rainas were both men and women. Most sites used hired labors (Table).

Women preferred to work more in kitchen gardening while the male preferred less (Table) because men were involved in outside activities for the welfare of their households. People of all study areas had good social vent about kitchen gardening. Insect-pest, diseases and lack of irrigation, improved seeds, fertilizers, credit, extension and marketing facilities and climatic hazards were the major problems faced by the farmers.

\section{Conclusions}

Women's involvement in kitchen gardening activities was highest in Rainas Municiaplity (Lamjung) and lowest in Kathmandu. However, in general women's labor contribution was relatively higher than men's labor contribution. There is possibility for increasing farm income by increasing female labor input in kitchen gardening activities. Women should be encouraged by providing training opportunities in different kitchen gardening activities, making the provision of credit, improved seeds, chemical fertilizers, irrigation and marketing facilities. Women's labor could be profitably used in kitchen gardening as it currently not utilized efficiently.

\section{Bibliography}

1. CBS. "Statistical Year Book of Nepal". Kathmandu, Nepal: Central Bureau of Statistics (2008).

2. WFFD. Annual Report, Ministry of Agriculture. Singhadurbar, Kathmandu, Nepal: Women Farmer's Development Division (WFDD) (2012).

3. Gautam R. Status of home gardens of Nepal: Findings of baseline survey conducted in four sites of home garden project (2002).

4. Subedi P. “Users' and Gender Perspectives of Agricultural Production". Pokhara, Nepal: LI-BIRD (2007).

5. Shrestha P. "Home garden in Nepal: status and scope for research and development". Witzenhausen, Germany: PB Editors (2001).

6. Suwal R. "Participatory Rural Appraisal (PRA) study of home garden project sites”. Nepal: LI-BIRD (2003).

7. UNDP. “Gender assessment study of agriculture sector". Kathmandu, Nepal: United Nations Development Program (2002).

Volume 3 Issue 8 August 2019

(C) All rights are reserved by Sujan Ghimire. 